\title{
The Interventionist Approach of Far-Right Politics and Implications for the Future of Liberal Democracy: A Case Study of India
}

\author{
Dr Hussain Shaheed Soherwordi* \\ \& Dr Sehrish Qayyum ${ }^{* *}$
}

\begin{abstract}
Economic self-sufficiency relies upon the 'Rechtsstaat' principle, or the rule of law, which reinforces the important attributes of liberal democracy i.e., upward control and political equality based on empirical research. The existence of far-right politics may seem implausible within liberal democracies due to endogenous variables, including power contestation, institutional malpractice, and corruption. Rather than accepting the marginalization of a subdued economic sector, liberal democracies require an in-depth research on the economic policies of coordination and collaboration to ensure their long-term survival. Scrutinizing the chronological development of far-right politico-economic trends reveals that a nation's survival depends upon democratic choices rather than fascist behaviour. Merely incremental advancements in nationalistic trends, including monopolization within the economic sector, can imperil a state's development. For instance, India is a large developing economy with options for experimentation and introducing new marketing trends,
\end{abstract}

\footnotetext{
* Dr Hussain Shaheed Soherwordi is Professor and Chairman of International Relations Department, University of Peshawar.

** Dr Sehrish Qayyum is Assistant Professor, Pakistan Navy War College, Lahore; and also a member of International Studies Association (ISA), USA.
}

@2021 by the Islamabad Policy Research Institute.

IPRI Journal $\square$ XXI (2): 131-148

https://doi.org/10.31945/iprij.210205 
Hussain Shaheed Soherwordi \& Dr Sehrish Qayyum

according to an international survey of safe market zones. Some of the world's largest retailers, such as "Best Buy", "Walmart" and "Amazon" have invested in India. In this paper, India's operation under the shadow of market capitalism is compared to the interventionist approach applied under a far-right political agenda. This case study analyses a real-world politico-economic situation and provides a triangulated argument for understanding the implications for the future of liberal democracy in the modern world.

Keywords: Far-right, RSS, Capitalism, Economic Globalization, Interventionist Approach 
The Interventionist Approach of Far-Right Politics and ....

\section{Introduction}

\section{Liberal Democracy in India}

7 he liberal democratic framework in India was conceptualized by Jawaharlal Nehru and crafted by Ambedkar, who created a formative constitution that pursued a "pacifist" and "nonalignment" policy during the Cold War due to the interaction between society, culture and liberal politics in India. This framework was justified by Rajni Kothari in his book Politics in India in 1970. ${ }^{1}$ After its inception in 1947, India flourished as a liberal democracy with a deliberate economic ideology of Nehru and the rise of a politically independent bourgeois class. However, after partition, despite having inherited a large industrial base, ports and a shipping industry as compared to Pakistan, it began to follow a non-neutral alignment policy to avoid political clashes and instability. India's subsequent support of the USA -- endorsing it in the Korean War in $1950^{2}$ and receiving food aid from 1949-57 - added sensitivity towards its international status due to the Cold War.

Liberal democracy was challenged in situation of wars in 1948 against Pakistan, and in 1962 against China. Kenneth Waltz's rubric of the second image is reversed due to the compelling effects of conflicts on liberal democracy, including the causal phenomena of commination, mobilization and warfare. This led to situation-centric policies. Shifting of the Indian interests towards the Soviet Russia was evident after 1955. Resultantly, the US chose Pakistan for its interests in a bi-polar world in order to dissuade isolation in the Asian block.

After 1970s, India's successful liberal democratic framework plunged into multiple crises, particularly in its institutional components. The issues of democratic rule began with the state of Emergency imposed by Prime Minister Indira Gandhi in $1974 .{ }^{3}$ The situation worsened and led to an institutional collision. The withdrawal of emergency in 1977 and call for general elections followed by the release of political prisoners; all

\footnotetext{
${ }^{1}$ Kothari, Rajni, "Politics in India”. Boston: Boston Little, Brown. 1970. Available at: https://ur.booksc.eu/book/53460565/c73b39

${ }^{2}$ Stebbins, Richard, "The United States in World Affairs." The Americas. 297. 1960.

Available at: https://www.jstor.org/stable/979535

${ }^{3}$ Grewal, J. Singh, "The Sikhs of the Punjab". Cambridge: Cambridge University Press. 1990. Available at: https ://www.vidhia.com/Historical\%2C\%20Political\%2C\%20 Philosophical\%20and\%20Informational/The_Sikhs_of_Punjab.pdf
} 


\section{Hussain Shaheed Soherwordi \& Dr Sehrish Qayyum}

highlight the beginning of efforts that clearly compromised the democratic governance.

Going back to the genesis of the Indian democratic order, one finds that it dates back to the emergence of the words "secular" and "socialist" in the political discourse. This resulted into the formation of the secular constitution during the Emergency in $1976 .{ }^{4}$ The early outlining of the Indian Constitution and its effectiveness in 1950, provided cultural reference points in the media for democratic growth and constitutional supremacy. Article 33 in the Ninth schedule of the Indian Constitution ${ }^{5}$ limited the powers of the armed forces, who have the potential to threaten parliamentary democratic rule through their unnecessary intervention into state politics, as has occurred repeatedly in Pakistan. Further, the undertaking of land reforms in 1961, 1996, 2003 and 2009 paved the way for liberal democratic rule to flourish at a grass-root level. Similarly, the Congress' rule had remarkable legislative achievements, setting precedents by excluding the military from politics and enabling the green and white revolution towards reaching self-sufficiency in the food sector. Indian liberal democracy, via its economic policies, was aimed to gain national economic self-sufficiency. ${ }^{6}$

However, in the last quarter of a century (1980-2015), the apparent liberal democratic route of the Indian politics clearly shifted towards the farright. The Rashtriya Swayamsevak Sangh (RSS), since its inception in 1925 , transitioned pronouncedly into a right-wing voice in the form of BJP, as its political front. The Indian polity of today is clearly undergoing a historically unprecedented process with the irresistible rise of the extreme right across culture, society, ideology and the economy, upsetting the institutional norms of liberal democracy. The populists, who seek to drive a wedge between liberalism and democracy by weakening the democratic regime, have adopted brutal blindness towards policies. There

\footnotetext{
${ }^{4}$ Kumar, Anand, "Secularism: Why Nehru and Indira inserted secularism in the constitution of India," Indian Express. 2017. Available at: https://indianexpress.com /article/research/anant-kumar-hegde-secularism-constitution-india-bjp-jawaharlal-nehruindira-gandhi-5001085/

5 Law and Justice Department, "The Constitution of India”. Delhi: Government of India. 1950. Available at: https://legislative.gov.in/sites/default/files/coi-4March2016.pdf

${ }^{6}$ Ward, Hugh, "Liberal democracy and sustainability". Environmental Politics, 17:3, 386409, 2008. DOI: 10.1080/09644010802055626 Available at: https://www.tandfonline. com/doi/citedby/10.1080/09644010802055626?scroll=top\&needAccess=true
} 
is a tacit involvement amongst the people, elected representatives and unelected experts. As mentioned in the analysis of the Independent on May 23, 2019, the marginalization of the Muslims, including their lynching in the name of "cow protection", the engineered rise of Hindus in bureaucracy, the media and the crushing of progressive movements in the cultural institutions and universities, have all occurred alongside an underperforming economy with the highest unemployment rate in 45 years. ${ }^{7}$ Unfortunately, the rise of the far-right in India has enabled jingoism and unfairly trumpeted Islamophobia, and calls for the survival of Hindu nationalism by hook or crook. In the view of a political analyst, Debaysh Anand (University of Westminster), the clash of civilizations has forced transformation in the cultural trends, religious inclinations and intolerant politics.

In India, a dominant power bloc has emerged that is defined by theories of race inherited from Nazi ideology, and a religio-cultural definition of nationhood. Under the regime of Prime Minister Narendra Modi, the Indian government is rapidly moving towards majoritarianism and marginalization of minorities while encouraging close alliance between the government and corporations. According to David Goodhart, a British analyst, democracies divide people into 'anywheres' and 'somewheres', referring to the professional identities and region-centric identities, respectively. Economic opportunities may affect 'anywheres,' while a populist approach may obscure 'somewheres.' Nevertheless, Modi's regime is following a populist approach and offering economic benefits that appeal to 'anywheres,' threatening the liberal future of democracy in India.

Seen through the lens of the Gramscian principle for enduring political power, the 2014 and 2019 elections were hijacked through the power of money from Hindu corporations. This cash was utilized by the RSS leadership for forced pre-cultural transformation before elections i.e., atrocities against Muslims, Christians and Sikhs. ${ }^{8}$ Modi, from another perspective, invited corporate interest in order to achieve a majority,

\footnotetext{
${ }^{7}$ Teitelman, Claire, "Communal Violence, Social Media and Elections in India" Journal of International Affairs, April 19, 2019. Available at: https://jia.sipa.columbia.edu/onlinearticles/communal-violence-social-media-and-elections-india

${ }^{8}$ Ahmad, Aijaz, "India: Liberal Democracy and the Extreme." Frontline, June 7, 2019. Available at: https://frontline.thehindu.com/cover-story/india-liberal-democracy-and-theextreme-right/article27315369.ece
} 


\section{Hussain Shaheed Soherwordi \& Dr Sehrish Qayyum}

marking a transition in the liberal age from political left to right. The French Rafael fighter aircrafts scandal (worth $€ 7.8$ billion) ${ }^{9}$ involving Prime Minister Modi and Ambani of the Reliance Group, is an evidence in kind of the rightwing offensive move towards economic selfsufficiency for a particular religio-cultural class of the Indian population. Despite this huge scandal, majority Hindus endorsed Modi in elections. For them Modi's corruption was a side issue. Congress' path to glory is now being brutally obstructed by the entrenched electoral machinery utilized by the RSS and the corporate sector. On the other hand, accusations of corruption are used more pronouncedly in Pakistan by the political parties to suppress each other and for the sake of nominal change in political faces, as recently seen in the 2018 election campaign. ${ }^{10}$

Modi's irresistible rise to power has also been partly due to the fact that never in the country's history has the fraternity of leading corporate CEOs united so strongly and volubly to promote a single politician for the prime ministership. ${ }^{11}$ The manipulation of 'anywheres' through economic incentives has also changed the fate of the Indian liberal democracy since 2019. RSS and BJP members manipulated the global expansionist stage for their interests and to promote the rise of the Hindu nationalism. Financial support from the corporate sector of Gujarat in particular, allowed Modi to become increasingly independent even of the RSS that had fostered him. ${ }^{12}$ The phalanxes of the RSS who supported him in elections could now be paid off with corporate cash.

\footnotetext{
${ }^{9}$ Singh, Sushant, "Air Force's 16-year wait over, Rafale deal done." The Indian Express, September 24, 2016. Available at: https://indianexpress.com/article/india/india-newsindia/air-force-16-year-wait-over-rafale-jet-deal-done-3046803/

${ }^{10}$ Turak, Natasha, "Terrorism, corruption and Chinese investment: The stakes in Pakistan's second-ever democratic election”. CNBC. July 25, 2018. Available at: https://www. cnbc.com/2018/07/24/terrorism-corruption-and-chinese-investment-the-stakes-in pakistans. html.

${ }^{11}$ Ulmer. Alexandra, and Ahmed Aftab, "Modi's war chest leaves India's election rivals in dust". Reuters, May 1, 2014. Available at: https://www.reuters.com/article/indiaelection-spending-bjp-congress-idINKCN1S7390

12 Gupta, D. Surajeet. Das, Sohini and Chatterjee, Dev, "Modi wasn't always India Inc's Narendrabhai. What explains the business community's fascination with Narendra Modi?" Business Standard. September 20, 2013. Available at: https://www.businessstandard.com/article/politics/modi-wasn-t-always-india-inc-s-narendrabhai113092001155_1.html
} 
The Interventionist Approach of Far-Right Politics and ....

This scenario is a real time instance of the interventionist approach of the far-right politics. The masses are maneuvered in favour of a certain class' narrative regarding the cultural, religious and politico-economic life of India through the marginalization of minorities and lower Hindu castes. The Nazi nationalistic ideology is mobilized to explain religious majoritarianism and religio-cultural revivalism in India's liberal democracy, shifting it towards social constructivism.

\section{The Indo-US Strategic Alliance: Economic Dimensions}

Political convergence and strategic certainties have instilled momentum in Indo-US bilateral relations. This impetus has been fueled by joint military exercises and strategic talks. Indian Prime Minister Modi's foreign policy is based on a hyper-chauvinistic and aggressive methodological approach. India's diplomacy may be revived under the influence of the US' actions, including economic and strategic agreements, for chasing dynamic strategic economic self-sufficiency and autonomy. After joining the Nuclear Supplier Group (NSG), Basic Exchange and Cooperation Agreement (BESA), Logistics Exchange Memorandum of Agreement (LEMOA) and the Communications, Compatibility and Security Agreement (COMCASA), turbulence on the commercial side of India-US strategic relations was assuaged enough to bear future possible jolts. However, America's challenging and unilateral plan of actions in the commercial sector will only intensify the issues of the Modi government. Maintaining an equilibrium within India's multi-layered ties with Iran and Russia would be the main concern. ${ }^{13}$ Washington's stumbling hidden policies towards India can be seen as a defective technique to impart new life into the Pax-Americana. ${ }^{14}$ In recent times, US-India relations came under stress when President Trump's strict commercial dealings revealed large differences and widened the gap between the policy prescriptions for a strategic reunion. Iranian and Russian ties may also disturb the balance of the Indo-US bilateral dynamics.

Likewise, declining warmth in Delhi-Tehran ties will cause sufferings for India's efforts to influence Central Asia. Although, the US has relieved

\footnotetext{
${ }^{13}$ Feng. Qian, "India Embraces the US at the cost of Russia Ties". Global Times. December 24, 2020. Available at: https://www.globaltimes.cn/content/1210947.shtml

${ }^{14}$ Kaura, Vinay, "US-India Relations at the Crossroads." The Diplomat, June 24, 2019.

Available at: https://thediplomat.com/2019/06/us-india-relations-at-the-crossroads/
} 


\section{Hussain Shaheed Soherwordi \& Dr Sehrish Qayyum}

the Iranian seaport of Chabahar, which allowed India to evade Pakistan. It created a trade corridor for Afghanistan free from retaliatory sanctions. Unfortunately, this situation can only remain functional for India if America's exemption of Chabahar remains stable, which is an unreliable factor. If Chabahar port stops receiving special treatment, it would be an exemplary instance of short-term American unilateralism surpassing longterm strategic amalgamation. ${ }^{15}$

India's strategic cooperation including LEMOA, COMCASA and BECA, with the US grew from a total of $\$ 7.7$ billion in 2004 to $\$ 28$ billion in 2017; the India-US bilateral trade nearly tripled from \$36 billion in 2005 to $\$ 104$ billion in 2014 , and aims to reach $\$ 500$ billion. ${ }^{16}$ In economic terms, this strategic alliance is a soft effort on the part of the US to balance out the presence of China in South Asia as India-China bilateral trade surpassed $\$ 100$ billion in 2018. Graham Allison's concept of Thucydides' trap - when existential threat is faced by the ruling elite from the rising elite, seems plausible if indirect anti-Pakistan US policy has led to a proliferation of boots on the Indian soil. China has invested $\$ 45$ billion in Pakistan under the CPEC project. On the other hand it has invested $\$ 70$ billion in India under the Bangladesh-China-IndiaMyanmar (BCIM) economic corridor and in almost 600 local companies as per data from the Times of India.$^{17}$ US involvement in India is readily apparent in several areas. The Indo-US Nuclear agreement, which originally devalued NPT, and US support for India in the NSG, facilitated India to exploit US-sourced oil and liquified natural gas on the Indian shores. Similarly, the Strategic Trade Authorization-1 status has helped India to shore up its civil, space and defense capabilities. ${ }^{18}$ On the other hand, economic interdependence and globalization has resulted into a

\footnotetext{
${ }^{15}$ Kaura, Vinay, "US-India Relations at the Crossroads." The Diplomat, June 24, 2019. Available at: https://thediplomat.com/2019/06/us-india-relations-at-the-crossroads/.

${ }^{16}$ Reuters Staff, "U.S. and India commit to building six nuclear power plants." Reuters. March 13, 2019. Available at: https://www.reuters.com/article/usa-indianuclearnuclearpower-idINKCN1QU2UM

${ }^{17}$ Rashid. Harun Ur, "BCIM Economic Corridor: A Giant Step towards Integration". Institute of Peace and Conflict Studies. 12 Nov 2013. Available at: http://www.ipcs. org/article/india/bcim-economic-corridor-a-giant-step-towards-integration-4172.html

${ }^{18}$ Staff Report, "US: India fulfils all conditions, but out of Nuclear Suppliers Group due to China's vet." The times of India, September 13, 2018. Available at: https://timesofindia. indiatimes.com/india/us-india-meets-all-qualifications-to-be-member-of-nsg/articleshow /65792316.cms
} 
unique capitalist system, where each country is largely dependent upon other countries for economic stability. Liberal democracy in India is shifting towards social constructivism with protectionist policies. These include the combination of dozens of levies in NST (North Shore Trade) enabling smooth cross-border trade, flagship policies like "Made in India," 19 increase in import duties, the food-security program, agricultural subsidies and banning of foreign retailers such as "Amazon" from striking exclusive deals with local goods sellers to discourage imports threatening the local economy. These steps preserve the Hindutva aims of the RSS and allow corporate cash to support the Modi regime. Interventionist policies, economic steps, and ties with the US are used to raise India as a regional superpower.

It is dangerous for India to be an enemy of the US, but it could prove fatal to be the US' friend, too. During the Republican tenure of Donald Trump, US policies were tilted towards India. However, as lucrative as India may seem, it is plunging into the Afghan cauldron. India is aggressively making efforts to interfere in Pakistan-Afghanistan borders, which may result in a setback for the Hindutva wave. By cutting the RSS budget for these activities, finances can be increasingly distributed for protection purposes within India. The emphasis could also be made to securitize the western borders. Cross-western border investments in Iran and Afghanistan may also be increased following US interests by and large. According to Reuters, RSS' economic wing wrote a letter to PM Modi asking him to oppose any date change for the new e-commerce policy implementation under US pressure, stating that it would affect 130 million small entrepreneurs. If the policy goes ahead, it will prevent e-commerce companies from selling products via organizations in which they have equity interests i.e. Amazon, eBay, PayPal etc. ${ }^{20}$

The RSS opposes a free market open to foreign players in India, placing a strong emphasis on self-reliance. ${ }^{21}$ Local retailers who survive by selling

\footnotetext{
${ }^{19}$ Choudhary, Gaurav, "Look East, Link West, says PM Modi at Make in India launch". Hindustan Times. September 25, 2014. Available at:

https://www.hindustantimes.com/business/look-east-link-west-says-pm-modi-at-make-inindia-launch/story-mGj6f6mlUmos0BAi27R11O.html

${ }^{20}$ Ahmad, Aftab and Kalra, Aditya, "Hindu group RSS urges India's Modi to resist U.S. push to ease e-commerce curbs." Reuters, January 25, 2019. Available at: https://www.reuters.com/article/us-india-ecommerce-exclusive-idUSKCN1PJ147 ${ }^{21}$ Ibid.
} 


\section{Hussain Shaheed Soherwordi \& Dr Sehrish Qayyum}

cheap goods accuse e-commerce companies of joining hands, sharing inventories and affiliations in order to create an unfair marketplace. In response, the RSS raised an opposing voice, saying that free trade market and fiscal policies should be barred. However, foreign investors argued against this reservation. For instance, the Walmart-owned Flipkart offered a trading platform to struggling entrepreneurs instead, with an online marketplace for traditional dresses, badminton racquets etc.

The bias towards a strict local industry based self-sufficiency and protectionism may limit the economic development of India. The far-right political trend in this liberal democracy risks dragging it towards aristocratic anarchism.

\section{Far-right Politics: A Comparison between Hindutva and RSS Supremacism}

Hindutva and RSS supremacism differ in both ideological sense and in reality. Hindutva "Hinduism" or Hindu Nationalism, as it is collectively referred to as an expression of social and political thought, is based on the native spiritual and cultural traditions of the Indian subcontinent. The term was disseminated by Hindu nationalist Vinayak Damodar Savarkar in 1923. It encapsulates three main aims: a common nation, a common culture and a common civilization exclusively for Hindus. All others were considered "outsiders". According to Christophe Jaffrelot, a political scientist specializing in South Asia, Savarkar declared himself an atheist, which "minimizes the importance of religion in his definition of Hindu," and instead emphasizes an ethnic group with a shared culture and geography. Jafferlot states that Savarkar was of the view that the biggest enemy of the Hindus are Muslims, and not Britishers. ${ }^{22}$

On the other side, RSS supremacists are staunch Hindus who believe in promoting Hindu supremacy in India even if that means carrying out the ethnic cleansing of minorities, especially Muslims, Sikhs and Christians. Gandhi was assassinated by Nathuram Godse, an RSS bigot. Godse has been glorified by the BJP for saving Hindu rights and supremacy. The height of RSS hatred can be seen in 2002 pogrom in Gujarat, after which Modi was banned from entering the USA, as a killer of humanity. Currently, it is the RSS faction among the government elite who are

\footnotetext{
22 Jaffrelot, Christophe, "Hindu Nationalism: A Reader”. Princeton University Press. August 19, 2007. Available at: https://press.princeton.edu/books/paperback/ 9780691130989/hindu-nationalism
} 
supporting Kashmir's ethnic cleansing of the Muslims in a struggle that has been underway for the last 72 years. The Hindu/Congress nationalism launched in 1885, trickled down into the extremist RSS narrative by 1925 , changing the cultural nationalism of Hindutva into political Hinduism and Hindu militancy. ${ }^{23}$ Currently, these ideologies promote religious chaos in this liberal age. In the vast context of ideology and religious behavior, the West has tried to limit the role of religion in politics and state affairs ever since the Treaty of Westphalia (1648). However, issues of race, culture and changing demographics (rising populations, particularly of the young and forced conversion of religion), may augment present problems for Muslims in the West and Europe. Despite living in Europe, the US and other Western countries for generations, Muslims have not been able to fully integrate in those societies.

Hindutva has developed an ominous life in India. Donald Eugene Smith in his book, India as a Secular State (1963), said that Nehru stated that Hindu socialism was the Indian type of fascism. The RSS follows key aspects such as the stereotyping of past greatness, ultra-chauvinism, religious naivety, national solidarity and the promotion of socio-racial dominancy with an isolationist approach towards ethnicity and religion. ${ }^{24}$ Fascism is honestly not a core inspiration of the RSS. It prioritizes the regeneration of Hindu socialism through accepted cultural change within the society rather than worshiping the state like fascists. As Virendra Prakash states in "Hindutva Demystified," the expression of Hindutva created by Savarkar and implemented by K.B. Hedgewar - Indian surgeon of RSS, as the foundational ideology of the Rashtriya Swayamsevak Sangh (RSS) is not a practical reality. ${ }^{25}$ Savarkar only tried to exploit Hindu sentiment and intellect to achieve his objectives. The Hindutva narrative is a tool used by the RSS supremacists to obtain corporate cash, and control over the governing body and state machinery. The RSS measures the rise of Hindus in the secular state of India against the negation of Nehru's vision for the sustainability of the liberal democracy. This is effectively the open murder of an Indian society of 1.33 billion. ${ }^{26}$

\footnotetext{
${ }^{23}$ Eugene, Donald, “India as a Secular State”. Princeton University Press. 2015. Available at: https://muse.jhu.edu/book/43712

${ }^{24}$ Ibid.

${ }^{25}$ Prakash, Virendra, "Hindutva Demystified". Virgo Publications. 2002. ISBN-10: 8185870330 ISBN-13: 978-8185870335 ${ }^{26}$ Ibid.
} 
Hussain Shaheed Soherwordi \& Dr Sehrish Qayyum

Global Maritime Order: Indian Far-Right Strategies to dominate the Indian Oceans' Maritime Sector

History, affluence and the security of 'sea powers' are inseparable from oceans. The Global Maritime Order (GMO) is a vast concept involving a focus on maritime security and maritime resource domains. Maritime security covers sovereignty, while maritime resources concern nontraditional threats. All sea powers, i.e., US, France, UK, China, Russia, keep military conflict and non-traditional threats to maritime sector separately. Traditional maritime defense is controlled under naval forces, while piracy and illegal crossings are countered by coastguards or ancillary protecting units. ${ }^{27} \mathrm{~A}$ brief overview of the GMO shows that a thin line has to be maintained between maritime security and the sustainability of oceanic resources. Parallel to this, the Indian Maritime Security Strategy (IMSS-2015) covers the maritime interests of the state, including the defense or security of Sea Lines of Communications (SLOCs), commerce and trade links. To materialize the Indian dream of hegemony over the Indian Ocean, IMSS-2015 entails claim of "Net Provider of Security," by overestimating its capacity. When Thucydides' trap is already appearing in the region, with an imbalance in the power equation with the rise of China contrary to the US, the Indian desire for domination seems farfetched. In 2017, India signed an agreement to buy High-tech Guardian Drones-Predator B in order to increase its grip on maritime surveillance in the IOR. ${ }^{28}$ These moves are merely a part of a hyperbolic rhetoric and India is bereft of a concrete maritime policy to fulfill its aim of being a "Net Security Provider" of the Indian Ocean. ${ }^{29}$ The center of the Indian maritime trade routes in the region may become

\footnotetext{
${ }^{27}$ Juneja, Mani, and Swati, Ghaneshan, "TERI-KAS RESOURCE DIALOGUE V On The Emerging Global Maritime Order - India 's Strategy.” terri.org. Terri-Konard, March 9, 2019. Available at: https://www.teriin.org/sites/default/files/2019-08/maritimestrategy.pdf.

${ }^{28}$ Gupta, Shishir, "India eyes acquisition of Predator-B drones from US". Hindustan Times News. July 06, 2020. Available at: https://www.hindustantimes.com/india-news/indiaeyes-acquisition-of-predator-drones-from-us/story-nVOOMnUWNh7KokbqE9uVY M.html

${ }^{29}$ Ullah, Sufiyan and Hayat, Zeeshan, "India as a Net Security Provider in Indo-Pacific and Implications for the Region". NUST Journal of International Peace \& Stability 2021, Vol. 4(1) Pages 26-39. Available at https://webcache.googleusercontent.com/search? q=cache:nOX20L2bRg4J:https://njips.nust.edu.pk/index.php/njips/article/download/77/7 $3 /+\& \mathrm{~cd}=10 \& \mathrm{hl}=\mathrm{en} \& \mathrm{ct}=\mathrm{clnk} \& \mathrm{gl}=\mathrm{pk}$.
} 
strangled if the Sino-US Conflict in South China Sea escalates. QUAD 2.0 is not sufficient to contain China, particularly when India has adjacent borders with China and the naval ports in its backyard. Consequently, rather than being contained, China must be engaged in trade and joint security projects, while India's dominant-dependent psyche may cost her in the conflict between global giants to dominate the Indian Ocean region.

Developments related to the Indian Ocean and an increasing defense budget to sustain India's place in the arms race is burdening its economy. The BJP's pro-national policies have shown selfishness despite finding options for lessening rivalries in the region. The IMSS-2015 aims to gain control of key points in the Indian Ocean to keep control of international trade in the Indian hands. For this purpose, the upgrading of QUAD to QUAD 2.0 in the military sector is raising questions of justifications as the high seas are not in anyone's jurisdiction. ${ }^{30}$ Meanwhile, the extended Indian presence in the Red Sea-Inlet to the Indian Ocean, near the strait of Babl-e-Mandab, the Gulf of Oman, the Gulf of Aden and their expanding area of operation into new chokepoints -- the Mozambique Channel and Ombai-Wetar Straits ${ }^{31}$-- may create maritime rifts in the region. Another important move of the BJP government, the launching of 'SAGAR Panchayat ${ }^{32}$ to enforce common order at sea by involving the Indian Ocean Rim countries, may pave the way for power dilemma.

Given the recent efforts of China and India among others to expand coastal state jurisdiction over maritime activities off their coasts, the US failure to join the Law of Seas (LOS) Convention will lead to likely

\footnotetext{
${ }^{30}$ Jha, Pankaj, "Is Quad 2.0 Transforming into Pentad?". Modern Diplomacy. May 4, 2021. Available at: https://moderndiplomacy.eu/2021/05/04/is-quad-2-0-transforminginto-a-pentad/

${ }^{31}$ Khurana, Gurpeet Singh, “Net Security Provider' Defined: An Analysis Of India's New Maritime Strategy-2015”. Center for International Maritime Security. December 4, 2015. Avaialble at: http://cimsec.org/net-security-provider-defined-analysis-indias-newmaritime-strategy-2015/20203.

${ }^{32}$ Editorial, 'Indian maritime Security Strategy'. Drishtiias. July 9, 2020. https://www.drishtiias.com/daily-updates/daily-news-editorials/india-s-maritime-securitystrategy
} 
Hussain Shaheed Soherwordi \& Dr Sehrish Qayyum

increased regional maritime challenges and confrontations. ${ }^{33}$ In this context, India has to carefully and deliberately move rather than blindly rely on US alliance.

\section{Economic Globalization in India: The End of Capitalism}

The collapse of communism is virtually the rise of liberal democracy and capitalism. As Francis Fukuyama in The End of History (1989) claims, historical progress is thought to be the human quest for freedom, and the end of the Cold War makes it clear that communism was merely an illusion, as demonstrated by the fall of the Soviet Union. Capitalism and liberal democracy are closely related as free markets to attract foreign direct investment which strengthen the state's economy and lead to selfsufficiency. However, in India, the rise of economic globalization with protectionist policies have brought an end to the free market-capitalism.

Samuel P. Huntington narrates in his essay "Clash of Civilization" (1993), that cultural divisions become a source of conflict among nations or groups of civilizations, as faults between civilizations may be latched on in the future and result in an intensified consciousness of civilization. History, language, culture, traditions and religion are the essentials of a civilization leading to social change and economic modernization. India moved to economic regionalism with strong contacts on global forums by reinforcing civilization consciousness, ultimately putting an end to pure capitalism in the country. ${ }^{34}$ Violence is, at times, used to achieve politicoeconomic objectives in India. It is claimed in Huntington's article that the demonization of Islam is achieved through a simplistic culturalist approach towards conflict.

The utopian ideology of influencing economics along nationalistic lines, as introduced by Henri de Saint Simon, may always remain an idea of inspired socialism rather than becoming a practical approach to handling

\footnotetext{
${ }^{33}$ Michel. David, and Sticklor, Russell, "Indian Ocean Rising: Maritime and Secuirty Policies Challenges”. Stimson Center Washington. D.C. 2012. ISBN: 978-0-98366746-9 Available at: https://www.stimson.org/wp-content/files/file-attachments/Book_ IOR_2_1.pdf

${ }^{34}$ Roy, Hindol, "Free market capitalism leads to greater economic democracy than socialism". The Print, July 10, 2021. Available at: https://theprint.in/yourturn/ subscriberwrites-free-market-capitalism-leads-to-greater-economic-democracy-thansocialism/693540/
} 
nations' economic self-sufficiency. ${ }^{35}$ India is a large developing economy and has options for experimentation and embracing new marketing trends, as per an international survey of safe market zones. For this reason, the world's largest retailers, including Best Buy, Walmart and Amazon invested in India. In an econometric sense, market capitalism in India has supported economic globalization with increasing participation from international business agencies, but has ended capitalism in a real sense.

Currently, the Indian economy under the effects of globalization, requires work in the following sectors: transparency in decision-making, according to internationally recognized standards, economic sector consolidation, public-private partnership and orderly improvement in conditional credit lines. Economic globalization may increase employment rates, production levels and quality due to free market competition. ${ }^{36}$ Historically, Indian right-wing political figures have supported market capitalism but after the 2002 anti-Muslim riots ${ }^{37}$ in Gujarat under Modi's Chief Ministership, economic trends took a U-turn. In order to save face, Modi focused on shifting capitalist economic trends towards economic globalization from 2014, attracting Hindu corporates to dominate the state's economy and giving them a majority part in GDP. This RSS-led BJP narrative of market flexibility paved the way for the soft-Indian reputation in world markets. Modi's "Act East" policy ${ }^{38}$ is also based on the rise of economic globalization in India and aims to secure a political paradigm shift from secular left to the Hindu nationalist right. This shift will give India more opportunities in rising Eastern economies in the globe i.e., Japan,

\footnotetext{
${ }^{35}$ Soliani, Ricarrdo, “Claude-Henri De Saint-Simon: Hierarchical Socialism?”. History of Economic Ideas Vol. 17, No. 2, The Political Economy Of Saint-Simonism (2009), pp. 21-39 (19 pages) Available at: https://www.jstor.org/stable/23723368

${ }^{36}$ Haqqani, Hussain, “India and the Global Economy”. Hudson Institute. July 2014. Available at: https://www.hudson.org/content/researchattachments/attachment /1420/indiaandthe_global_economy_hudson.pdf

${ }^{37}$ Clark-Decès, Isabelle, "A Companion to the Anthropology of India”. John Wiley \& Sons. February 4, 2011. Print ISBN: 9781405198929 | Online ISBN: 9781444390599 |DOI:10.1002/9781444390599 Available at: https://onlinelibrary.wiley.com/doi/book/10. 1002/9781444390599

${ }^{38}$ Staff Report. "Modi govt to give greater push to India's Look East Policy, says Sushma Swaraj."First Post, August 25, 2014. Available at: http://www.firstpost.com/business/ economy/modi-govt-to-give-greater-push-to-indias-look-east-policy-says-sushmaswaraj-2011353.html
} 
Malaysia, Australia, and China, rather than investing more in the western economies to gain international repute and economic strength.

\section{The Interventionist Approach of Far-Right Politics in India}

The convergence of corporate cash and BJP nominations, particularly in Narendra Modi era, shifted the trends of the free market. The provision of far-reaching benefits due to the rise in commercial cash is part of an interventionist approach in favour of extreme-right political notions. Actually, the low taxation rate has attracted the FDI in liberal democracies, and India benefitted from this trend by supporting its small entrepreneurs' partnerships with local business elite. So, directly or indirectly, the corporate sector is being incorporated into politics, the economy, social practices, and traditional events. For example, businesses make offers attached to Holi, Diwali, Visakhi, Dosehra, and Ganpati Visarjan and invest in narrative building during elections and social awareness campaigns, as explained by the Business Standard News (BSN). ${ }^{39}$ The utopian ideology of influencing economics along nationalistic lines is becoming dystopian; socialism-inspired economic self-sufficiency for nations is being promoted. Although India is moving towards self-sufficiency, it is not equally for the whole population but only for the extreme right, i.e. RSS followers and Hindus, because majority of the corporate world supports the RSS creed. The interventionist behaviour of the RSS-led BJP has cut short equal development in India, particularly among ethnic minorities. The characteristics of liberal democracies are shifting towards an amalgamation of neoliberal economic policies and electoral democracies where opportunities are class-oriented.

Under Modi, India is fast becoming a Hindu state. A transformation is taking place in the country's secular outlook which dates back to the Gandhi-Nehru era. Ambedkar, a Dalit, authored the Indian constitution under Nehru. Since Lok Sabha is overwhelmingly controlled by BJP, any legislation tabled by the party will be passed, or rather bulldozed through. When Article 370, which provided special status to the Indian occupied Kashmir, was recently revoked ${ }^{40}$ only a few strong voices against it were

\footnotetext{
${ }^{39}$ Kumar, Anand, "Business offers analysis at traditional events." Business Standard News, February 03, 2019.

${ }^{40}$ Editorial, "Article 370: What happened with Kashmir and why it matters." BBC News,

August 6, 2019. Available at: https://www.bbc.com/news/world-asia-india-49234708
} 
heard. The rule of non-majoritarianism, embedded in the Gandhi-Nehru philosophy and the original constitution of India is now under threat by a majority rule which strikes at the heart of liberal democracy. Today, the BJP under Modi is vigorously advancing the philosophy of Hindutva which seeks India exclusively for Hindus, with all others cast as "outsiders." Where it would lead to is not yet known, but one thing is clear, India will never be the same as it has been under the Congress.

\section{Conclusion}

It is clear that liberal democracy in India is now facing an existential threat to its survival due to the liberal age revival of the political swing from left to extreme right. Democracy is a unique governing and administrative system, which counts majorities and minorities as equal while taking decisions. In a liberal democracy, far-right politics are implausible because liberal democrats work under the influence of a liberal political ideology operating with the principles of classical liberalism. Whirling upside down, India is currently working for the supremacy of Hindutva, RSS ideology and the rise of the BJP, aiming to make India a Hindu state. The BJP, in the former and current regime, is using an interventionist approach to interfere in the corporate sector and divert investment in favour of the Hindu community rather than equally distributing profit and gain to the whole population, as attributes of liberal democracies. Presently, the situation is moving towards "stagflation," yet the popularity of Narendra Modi has risen.

Rather than following the marginalization of the subdued economic sector, as present in far-right political trends, liberal democracies need indepth research on economic policies, concerning coordination and collaboration for long-term survival. We believe that it is the responsibility of the liberal democratic governments to consider realistic plans for market capitalism in developing politico-economic policies. This will result in the smooth growth of the state's economy, which in turn adds to the solidarity and security of the state. Without such practices, Liberal democracy in India may turn to fascism and brutality will pave the way for revolution rather than evolution.

It is, therefore, recommended that economic anxieties need to be tackled fore-mostly, for the survival of liberal democracy, which is sharply declining into populist nationalism in India. Secondly, consciousness of competing civilizations should be eradicated as much as possible, as identity politics is causing political decay and promoting bigotry. Thirdly, 
Hussain Shaheed Soherwordi \& Dr Sehrish Qayyum

promotion of social integration for inclusive nationalism rather than shifting liberal democracies to the illiberal will serve as a cohesive bond. Fourthly, funding (corporate cash) should be managed and controlled. Last but not least, trade liberalization should be given terms and conditions to promote secure economic prospects. 